\title{
Exploration of the Adversity Quotient Laboratory Assistants of Public Universities in Indonesia
}

\author{
Merry Dandian Panji ${ }^{1}$, Makruf Akbar ${ }^{2}$, Unifah Rosyidi ${ }^{3}$ \\ \{ sripangeran7@gmail.com ${ }^{1}$, marufakbar@gmail.com ${ }^{2}$ \} \\ ${ }^{123}$ Universitas Negeri Jakarta, Indonesia \\ ${ }^{1}$ Head Section of Career Regional Education Staff I, Ministry of Research, Technology, and Higher \\ Education, Indonesia
}

\begin{abstract}
The Indonesian government through the Ministry of Research, Technology, and Higher Education paid much attention to the lecturer's opportunities to upgrade their professional skills. It was essential to investigate the factors that impact the workability of this upgrade to educators (lecturers) and also the educational staff. This study, aimed at describing the level of adversity quotient (AQ) of the educational laboratory assistants, influenced the quality of service of educational laboratory assistants of some public universities. This survey involved 23 laboratory assistants from 16 Universities in Indonesia. The adversity quotient was measured by 21 items of Ketahan Malangan scale with five dimensions, namely: motivation, adaptation, integration, control and endurance with a correlation approach. The data were analyzed through descriptive statistics and shown through pie charts. The results of this study indicate that the level of AQ, by all dimension, was measured in the high level.
\end{abstract}

Keywords: Education Laboratory Assistant, effective coaching, adversity quotient and quality service

\section{Introduction}

To improve the quality of higher education, the Indonesian government, through the Ministry of Research and Technology and Higher Education, gave much attention to lecturers and all education staff. This effort is carried out with the aim of improving the welfare of the educators as well as providing opportunities to improve their professionalism. The Ministry oversees all education staff with various levels of position including the Educational Laboratory Assistants under the direct guidance of the Ministry.

A reflection on the model for effective coaching exposed that coaching is rooted in the theory of adult learning and lifelong learning. This model reflects the transformational learning process and uses processes related to the learning experience and mentoring theory [1]. In relations to that, the research that we have done later revealed that the coaching process, in fact, facilitates dynamic exchange between no less than 18 learning theories. Among them are collaborative learning, mentoring, independent learning, social learning, reflective learning, adult learning, experiential learning, transformative learning, in-depth learning, authentic learning, action learning, inductive learning, discovery learning, strong learning, lifelong learning, learning accelerated, problem-based learning and emotional intelligence [2].

There were 1722 laboratory staff from 16 universities, who have different levels of ability in producing quality services, despite been involved in coaching efforts. Of the number of staff 
described in table 1 above, the highlighted ones were those that had become civil servants. The government of the Republic of Indonesia appointed them with a functional position from the Education Laboratory Officer. The functional position of the Educational Laboratory Assistant is included in the position of the education group and is placed as a functional technical implementer in the field of laboratory management. Their main task is to manage the laboratory through a series of activities, such as designing, operating tools and materials, maintaining equipment and materials, evaluating laboratory work systems, and developing laboratory activities in the context of developing laboratory professional education. Like other professional workers, the Education Laboratory Assistants have an organization that protects them, which is the Indonesian Educational Laboratory Organization Association.

\section{Literature Study}

The important element in providing quality services is the sustainability of Adversity Quotient (AQ); this is a person's ability when placed in a miserable condition. This is one important factor in supporting the quality of good services [3]. AQ is about various competencies especially productivity, motivation; the ability to take risks, improve, persevere, and learn. Stoltz also discussed the existence of three levels of human groups in difficult situations in relations to AQ [3]- Quitters are those who avoid difficulties. The other groups are Campers. They are those that are easily satisfied with the situation, not having the desire to fight harder. Campers are different from the first group of Quitters, who don't want to take the risk at all. In this group, they are daring and ready to face problems and try to solve them. However, after overcoming the problem, they are satisfied and consider that as their success. Lastly, we have the Climbers. They are optimistic and see opportunities as well as the possibility of a gap. No matter what, they see a speck of hope behind despair. Thus, they always are always passionate about moving forward. The climbers are thinkers. They always try to get challenges and never give up [4].

The ability to survive under stressed conditions (resilience) is a matter that must be possessed by the Education Laboratory Staff in carrying out activities involving laboratory use. AQ is a new and useful concept that is needed to face challenges in everyday life [5]. AQ also supports that interest in adversity quotient is related to that of the academic field. AQ is very essential in supporting achievements and acts as an indicator (besides IQ, EQ) of one's achievements [4].

Administratively, Education Laboratory Assistants are required to fulfill the many and complex personnel administration requirements when applying for promotions or positions since they will be receiving government benefits from Education Laboratory Assistant. Even at that, Education Laboratory Assistants must manage their expertise according to their respective fields. AQ is one of the dimensions contained in the quality of service. To check it, there is a need to determine if they are responsible, competent, have good values, can be trusted, safe, easily accessible, communicative and understand customers [6].

\section{Research Method}

The objective of this study is to describe the level of adversity quotient of the laboratory assistant. The population of this study is the entire laboratory assistants at 16 Indonesian 
Universities as shown in table 1 . There were 23 laboratory assistants selected through random sampling from 16 Public Indonesian Universities involved in this study.

Table 1. List of Education Laboratory Staff in State Universities in Indonesia

\begin{tabular}{|c|c|c|c|c|}
\hline \multirow[t]{2}{*}{ Collage } & \multicolumn{4}{|c|}{ Population } \\
\hline & Skilled & Expert & & All \\
\hline Universitas Gadjah Mada & 29 & 171 & 200 & \\
\hline Institut Pertanian Bogor & 44 & 153 & 197 & \\
\hline $\begin{array}{l}\text { Institut Teknologi Seuuh } \\
\text { November }\end{array}$ & 11 & 65 & 76 & \\
\hline $\begin{array}{l}\text { Politeknik Negeri } \\
\text { Payakumbuh }\end{array}$ & 30 & 45 & 75 & \\
\hline Universitas Airlangga & 18 & 56 & 74 & \\
\hline Universitas Andalas & 23 & 51 & 74 & \\
\hline $\begin{array}{l}\text { Politeknik Negeri } \\
\text { Lhoksumawe }\end{array}$ & 46 & 27 & 73 & \\
\hline Universitas Tadulako & 40 & 32 & 72 & \\
\hline Universitas Diponegoro & 26 & 43 & 72 & \\
\hline Politeknik Negeri Ambon & 27 & 41 & 68 & \\
\hline Universitas Brawijaya & 11 & 57 & 68 & \\
\hline $\begin{array}{l}\text { Institut Teknologi } \\
\text { Bandung }\end{array}$ & 8 & 59 & 67 & \\
\hline Univseritas Udayana & 23 & 39 & 62 & \\
\hline $\begin{array}{l}\text { Politeknik Pertanian } \\
\text { Negeri Samarinda }\end{array}$ & 17 & 40 & 57 & \\
\hline Politeknik Negeri Jember & 22 & 34 & 56 & \\
\hline $\begin{array}{l}\text { Politeknik Negeri } \\
\text { Bandung }\end{array}$ & 4 & 51 & 55 & \\
\hline Total & 1343 & 379 & 1722 & \\
\hline
\end{tabular}

The data of AQ was collected by 21 items Ketahan Malangan scale (the Indonesian version of adversity quotient scale). There, 5 dimensions of AQ were measure on this scale, namely: (1) motivation, (2) adaptation, (3) integrations, (4) control and (5) endurance. The dimension is taking from Stoltz Adversity Quotient theory. The survey was conducted online between July to December of 2018 and was performed by Google docs forms. The data of this study is described in pie charts. All the datasets of this study are accessible online at https://osf.io/bxk2n/ from open science frameworks' (osf) [7].

\section{Result and Discussion}

\subsection{Motivation}


$47.8 \%$ of the 23 respondents strongly agreed that the existence of guidance from the appointed university leaders motivated human resources to improve their careers in higher education. For example, by providing opportunities to take technical guidance as well as opportunities for study assignments related to laboratory development. $47.8 \%$ of the 23 respondents agreed that there was guidance given by the university leaders appointed by giving education Laboratory Assistant the opportunity to attend education and training on how to foster a positive mental attitude in the face of difficulties in the workplace. This results exactly show the participants of this study have a high level of motivation. The results of the level of motivation have been described.in figure 1 below.

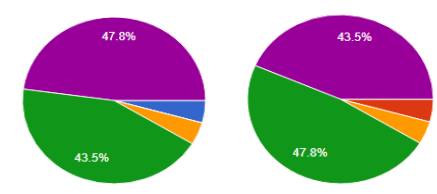

\subsection{Adaptation}

Fig. 1. Motivation

As shown in table 2, 34.8\% of 23 education Laboratory Assistants agreed that university leaders or designated officials provide knowledge to adjust to laboratory users so that the atmosphere becomes comfortable. Meanwhile, 56.5\% of these respondents agreed that the leaders of higher education or designated officials provide guidance on mental attitudes to Education Laboratory Assistants. And this was done with the aim of adapting to the laboratory users. The results indicate a high rate in the level of adaptation of the participant studied.

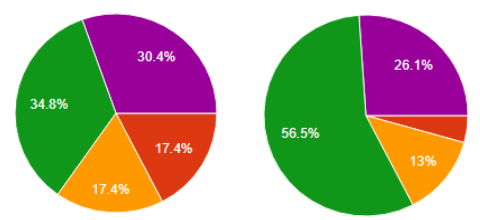

Fig. 2. Adaptation

\subsection{Integrations}

In table 3, 43.5\% of 23 Education Laboratory Assistant respondents strongly agreed that if the higher education leaders or appointed officials provide guidance, the Education Laboratory Assistant can work with the laboratory team. $43.5 \%$ agreed that there would be efficiency if the leaders of higher education or designated officials provide education and training related to relations and cooperation with stockholders. The results of this study indicate most of the participant study has a high level of integration ability.

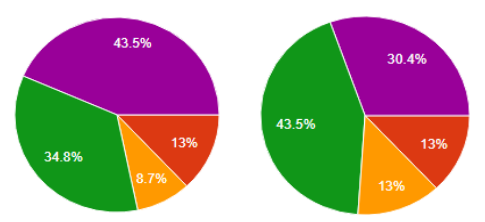


Fig. 3. Intergration

\subsection{Control}

In table 4, 75\% of respondents agreed that Education Laboratory Assistants always get complaints from laboratory users before finally answering their complaints. $81.3 \%$ participants agreed to remain calm in facing criticism from laboratory users. The results of this study indicate the control dimension of AQ of participants of this study at a high level.

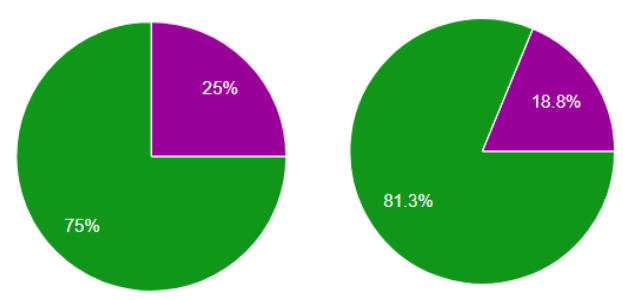

Fig. 4. Control

\subsection{Endurance}

The level of endurance as shown in table 5 indicates that $75 \%$ of respondents agreed to receive reprimand and criticism given by laboratory users in relations to the care handled by Education Laboratory Assistant. 87.5\% of the respondents agreed that the tasks given by superiors related to the laboratory were carried out and were received with pleasure. This result also shows that the level of endurance of the participant study is high.
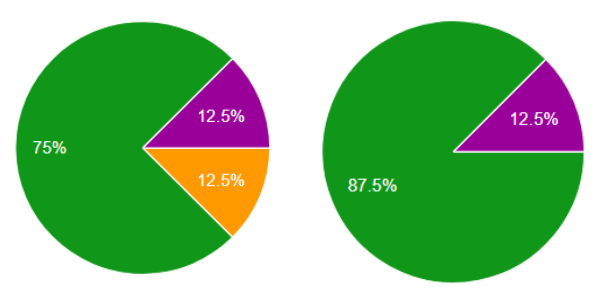

Fig. 5. Endurance

\section{Conclusion}

The result of this study has shown that the level of adversity quotient of the Education Laboratory Assistant is at a high level. The adversity quotient level was measured from 5 
dimensions, namely motivation, adaptation, integration, control and endurance, all in the high level. This condition should support the achievement of optimal performance, considering that the theory states that AQ levels contribute to performance achievements. Further investigation is needed to ascertain that this high level of AQ has supported the optimal performance of the University Education Laboratory Assistants.

\section{References}

[1] Kerryn Griffiths.. (2006). Personal Coaching: A Model for Effective Learning. Journal of Learning Design, Volume 1 Issue 2: 1, (2006).

[2] Smither, James W., and Susanne P. Reilly. "Coaching in organizations." How people evaluate others in organizations (2001): 221-252.

[3] Stoltz, Paul G. Adversity quotient: Turning obstacles into opportunities. John Wiley \& Sons, (1997).

[4] Suranata, K. Pengaruh Model Bimbingan Konseling Self Management terhadap Adversity Quotient Siswa SMA, Jurusan Bimbingan Konseling, Undiksha, (2007).

[5] Matore, M. E. Influence of AQ on the Academic Achievement among Malaysian Polytechnic Students“. Journal International Education Studies Volume 8 No. 6, (2015).

[6] Clampitt, Phillip; Williams, M. Lee; Dekoch, Robert. Embracing uncertainty: The executive's challenge. Journal of Change Management, 2.3: 212-228, (2001)

[7] Merry. AQ Dataset.” OSF Preprints. January 3. (2019), doi:10.31219/osf.io/bxk2n 